Original article

\title{
The apoptotic activity of flavonoid-containing Gratiola officinalis extract in cell cultures of human kidney cancer
}

\author{
Natalya V. Polukonova ${ }^{1}$, Nikita A. Navolokin ${ }^{1}$, Alla B. Bucharskaya ${ }^{1}$, Dmitry A. Mudrak ${ }^{1}$, Maria A. Baryshnikova ${ }^{2}$, \\ Eugenia V. Stepanova ${ }^{2}$, Eliso S. Solomko ${ }^{2}$, Anna V. Polukonova ${ }^{1}$, Galina N. Maslyakova ${ }^{1}$ \\ ${ }^{1}$ Saratov State Medical University, Saratov, Russia \\ ${ }^{2}$ N.N. Blokhin National Medical Research Centre of Oncology, Moscow, Russia
}

Received 13 September 2018, Accepted 11 October 2018

(C) 2018, Polukonova N.V., Navolokin N.A., Bucharskaya A.B., Mudrak D.A., Baryshnikova M.A., Stepanova E.V., Solomko E.S., Polukonova A.V., Maslyakova G.N.

(C) 2018, Russian Open Medical Journal

Abstract: Objective - The discovery of the apoptosis-inducing effects of flavonoid vagonin allowed to make an assumption of existence of similar effect in others flavonoids. This study is devoted to the effects of Gratiola officinālis extract on cell culture of the human kidney cancer.

Methods - Cell cultures of human kidney carcinoma - Caki-1 and SN12c were used in the study. The cells were stained with Hoechat 33258 dye. The number of living cells, cells in a state of apoptosis and mitosis were counted. The Cramer-Welch criterion (T) was used to compare the obtained data.

Results - The activation of apoptosis was noted at all concentrations of the Gratiola officinalis L. extract during the first day of exposure. The apoptotic activity increased with increasing of extract concentration. After 48 hours, this activity was maintained only at a Gratiola officinalis L. extract concentration of $0.9 \mathrm{mg} / \mathrm{ml}$. After 24 hours, the apoptotic activity of the extract was more expressed in the culture of CaKi-1. However, after 48 hours the extract induces more pronounced apoptosis in the culture of Sn12c cells. The cytotoxic activity of the extract was not differ after 24 hours in both cultures, after 48 hours it was more pronounced in the culture of CaKi-1.

Conclusion - We revealed a pronounced antitumor and apoptotic activity of the Gratiola officinalis L. extract against the cultures of the kidney cancer Caki-1 and Sn12c. Apoptosis of tumor cells can be manifested in the form of pycnosis of the nucleus, the formation of apoptotic bodies and the emergence of cellular debris resulting from complete degradation of tumor cells. The apoptotic activity of the Gratiola officinalis extract depends on their concentration.

Keywords: flavonoids, Gratīola officinālis, kidney cancer, Caki-1, SN12c, apoptosis.

Cite as Polukonova NV, Navolokin NA, Bucharskaya AB, Mudrak DA, Baryshnikova MA, Stepanova EV, Solomko ES, Polukonova AV, Maslyakova GN. The apoptotic activity of flavonoid-containing Gratiola officinalis extract in cell cultures of human kidney cancer. Russian Open Medical Journal $2018 ; 7$ : e0402.

Correspondence to Nikita A. Navolokin. Address: Department of Pathological Anatomy, Saratov State Medical University, Bolshaya Kazachya str., 112, Saratov, 410012, Russia. E-mail: navolokin1@rambler.ru.

\section{Introduction}

The number of patients with oncological diseases is steadily increasing. Modern methods of treatment are not always sufficiently effective. The used antitumor drugs have some drawbacks: a toxic effect on healthy organs and tissues of the body, as well as the development of tumor resistance to treatment. Therefore, the search for new, more safe and effective medicines is an important challenge today [1, 2].

Medicinal products of plant origin have minimal side effects; therefore, special attention is paid to them today. Plant extracts can be used not only in the form of monotherapy, but also in complex tumor treatment. Flavonoids are able to protect normal cells (including bone marrow stem cells) during the standard course of chemo- and radiotherapy [2, 3].

Flavonoids are one of the most promising groups of biological compounds. They have the greatest number of biological effects for the tumor treatment [3]. Some flavonoids are able to activate apoptosis in tumor cells, for example, Vagonin. The apoptotic activity of the flavonoid Vagonin allowed to continue the search for other bioflavonoids with antitumor activity as well as study of mechanisms of their biological activity $[3,4]$.

Previously, we have developed a method for separation of flavonoid-containing extracts from Gratiola officinālis $L$. that allows obtaining non-toxic or low toxic extracts even from poisonous plants $[5,6]$. It is know that these extract have antioxidant [7, 8], antitumor [9-13], antimicrobial and antiinflammatory [14, 15] actions.

However, the detail examination of mechanisms of such biological activity of Gratiola officnalis extract was not conducted yet.

The aim of research: to study the morphological changes of cells in human kidney carcinoma Caki-1 $и$ SN12c in experiments in vitro after exposure of Gratiola officinalis extract. 

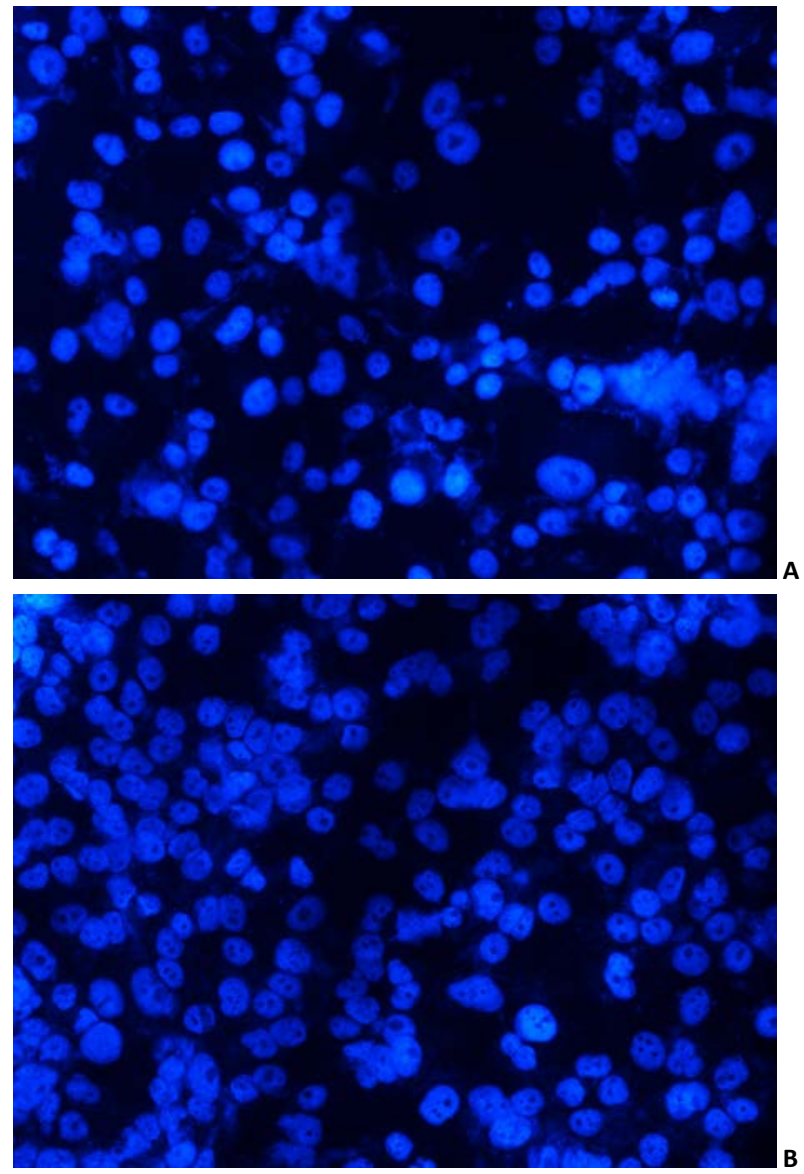

Figure 1. Cells of the Cake line without exposure (in the control): A) after 24 hours; B) after 48 hours in fluorescence mode (at $435-485 \mathrm{~nm}$ ), Hoechst 33258 staining. $\times 200$.

\section{Material and Methods}

\section{Gratiola officinalis extract}

Flavonoid-containing extract from Gratiola officinalis raw material is used for the study. The author's method for obtaining the extract was developed previously $[5,6]$.

The composition of Gratiola officinalis flavonoids has not been studied thoroughly. Some compounds are known for Gratiola extract: gratiogenin, 16-hydroxygratiogenin, cucurbitacins-E, glycosides gratiogenin-3 beta-D-glucoside, gratioside, elaterinide, lignans, traces of alkaloids, coumarin derivatives and mannitol, betulinic acid [16-20].

The chemical analysis of Gratiola extract, which was performed by gas chromatography-mass spectrometry, showed by the presence of quercetin bioflavonoid in it, as well as: 4-vinyl-2methoxyphenol, 2,3-dihydro-3,5-dihydroxy-6-methyl-4H-pyran -4one, 2,3-dihydrobenzofuran, 3-furancarboxylic acid, 5hydroxymethyl-2-furaldehyde, ethyl-d-ribozide, 4-propylphenol, pyrocatechol, L-luxose (pentose), 6-deoxyhexose L- galactose, ethyl ester of benzoylacetic acid, palmitic acid, homovanilic acid, glucose, 1,4-anhydro-d-mannitol, benzoic acid and gallic acid lots.

The evaporated extract, yellow-brown in color, can be mixed with water and ethyl alcohol in any proportions. Standartization of flavonoid-containing extracts was performed by quercetin and rutin. Mean of quercetin concentration in Gratiola officinalis extract was determined from a calibration curve using a standard sample of quercetin (Sigma, 98\%) and should not be less than $0.66 \%$. The amount of quercetin was 350 micrograms in dry extractives residue as was defined by high performance liquid chromatography (HPLC). The qualitative reactions with crystalline magnesium and Wagner-Bouchard reagent testify to the presence of bioflavonoids and the absence of alkaloids in obtained Gratiola officinalis extract.

\section{Cell lines}

Cultures of human tumor cells of human kidney carcinoma Caki1 and SN12c were used in the study. Cell cultures were obtained from the Bank of Cell Lines of N.N. Blokhin National Medical Research Centre of Oncology (Moscow, Russia). The lines were cultured on a complete RPMI-1640 culture medium (PanEco, Russia). The nutrient medium contains $10 \%$ fetal bovine serum (TPP, HyClone, USA), $2 \mathrm{mM} / \mathrm{ml}$ glutamine (PanEco, Russia), $50 \mathrm{mg} / \mathrm{ml}$ penicillin-streptomycin (PanEco, Russia). Cells with a 70-80\% monolayer were used for experiments. The following parameters were used: a temperature of $37^{\circ} \mathrm{C}$ and a content of $5 \% \mathrm{CO}_{2}$.

\section{Immunocytochemical study}

Cells were grown up to $70 \%$ of the monolayer on the glass. After incubation with the extract during 24 hours, cells were fixed in alcohol and acetone. Then, the cells were stained with Hoechat 33258 dye $(1 \mu \mathrm{g} / \mathrm{ml}$, PanEco, Russia). Hoechat binds to the structures of the cell nucleus and causes their bright glow. We conducted the morphological examination on fluorescence microscope Nikon 80i (Japan) at 435-485 $\mathrm{nm}$. The following indicators were used: the average number of living cells in the field of view (LCFV), the proliferation index - the ratio of LCFV after extract exposure to the LCFV in the control, \% of cells in metaphase, anaphase and telophase from the total number of cells, $\%$ of cells in apoptosis, $\%$ of cells with pycnosis of the nucleus from the total number of cells with signs of apoptosis, percentage of apopotic bodies from the total number of cells with signs of apoptosis. Cell counting was performed in each group in at least three fields of view with magnification of $\times 200$.

\section{Statistical analysis}

In the statistical processing of data, the normality of the distribution of the indicators was verified in groups using the Shapiro-Wilk test. The Cramer-Welch criterion ( $T$ ) was used to compare obtained average values, the difference between the arithmetic mean of the two samples (control and experimental) is divided into a natural estimation of the standard deviation of this difference. The mean difference with a probability of $95 \%$ is determined with this method at $T \geq 1.96$ and $p<0.05$. All statistical analysis is carried out using STATISTICA 10.0 Interprise software (StatSoft, USA).

\section{Results}

\section{Cell culture Caki-1}

Low mitotic activity (percentage of cells in metaphase, anaphase and telophase phases of mitosis $1.2 \pm 0.3 \%$ ) and weak apototic activity were observed after 24 hours in control cell culture of Caki-1 without exposure (Figure 1). Signs of apoptosis and mitosis were not observed in the cells after $48 \mathrm{~h}$ (Figure 1B), LCFV increased by $8 \%$. 
Table 1. Morphometric parameters of Caki-1 cells after exposure of Gratiola officinalis extract

\begin{tabular}{|c|c|c|c|c|c|c|}
\hline \multirow{2}{*}{$\begin{array}{l}\text { Groups ( } \mathrm{mg} / \mathrm{ml} \text { extract } \\
\text { concentration) }\end{array}$} & \multirow[t]{2}{*}{ LCFV } & \multirow{2}{*}{$\begin{array}{l}\text { The index of } \\
\text { proliferation }\end{array}$} & \multirow{2}{*}{$\begin{array}{l}\text { \% of cells in metaphase, } \\
\text { anaphase and telophase }\end{array}$} & \multirow{2}{*}{$\begin{array}{l}\text { \% apoptosis's cells in } \\
\text { field of view }\end{array}$} & \multicolumn{2}{|c|}{ \% cells in apoptosis } \\
\hline & & & & & Pyknosis & Apoptotic bodies \\
\hline \multicolumn{7}{|c|}{ After 24 hours } \\
\hline Control & $172.7 \pm 10.8$ & 1 & $1.2 \pm 0.3$ & $2.1 \pm 0.3$ & $49.2 \pm 11.5$ & $50.8 \pm 11.5$ \\
\hline Extract $0.035 \mathrm{mg} / \mathrm{ml}$ & $168.0 \pm 7.5$ & 0.97 & $2.5 \pm 0.3^{*}$ & $10.0 \pm 0.6^{*}$ & $80.7 \pm 1^{*}$ & $19.3 \pm 1.0 *$ \\
\hline Extract $0.18 \mathrm{mg} / \mathrm{ml}$ & $154.6 \pm 14.7$ & 0.89 & $1.2 \pm 0.4$ & $13.3 \pm 1.6^{*}$ & $86.2 \pm 2.9 *$ & $13.8 \pm 2.9^{*}$ \\
\hline Extract $0.9 \mathrm{mg} / \mathrm{ml}$ & $63.3 \pm 6.7^{*}$ & 0.37 & $0.0 \pm 0 *$ & $19.7 \pm 2.5^{*}$ & $96.7 \pm 2.1^{*}$ & $3.3 \pm 2.1 *$ \\
\hline \multicolumn{7}{|c|}{ After 48 hours } \\
\hline Control & $187.0 \pm 8.7$ & 1 & $0.0 \pm 0$ & $0.0 \pm 0$ & $0.0 \pm 0$ & $0.0 \pm 0$ \\
\hline Extract $0.035 \mathrm{mg} / \mathrm{ml}$ & $2.0 \pm 0.1^{*}$ & 0.01 & $0.0 \pm 0$ & $0.0 \pm 0$ & $0.0 \pm 0$ & $0.0 \pm 0$ \\
\hline Extract $0.18 \mathrm{mg} / \mathrm{ml}$ & $1.0 \pm 0.4 *$ & 0.01 & $0.0 \pm 0$ & $0.0 \pm 0$ & $0.0 \pm 0$ & $0.0 \pm 0$ \\
\hline Extract $0.9 \mathrm{mg} / \mathrm{ml}$ & $5.5 \pm 1.0$ & 0.03 & $0.0 \pm 0$ & $22.9 \pm 6^{*}$ & $50.0 \pm 28.9 *$ & $50.0 \pm 28.9 *$ \\
\hline
\end{tabular}

Data presented as mean with standard deviation - M \pm SD. LCFV, the average number of living cells in the field of view. ${ }^{*}-$ The differences are significant compared to the control group at $\mathrm{p}<0.05$ and $\mathrm{T} \geq 1.96$.
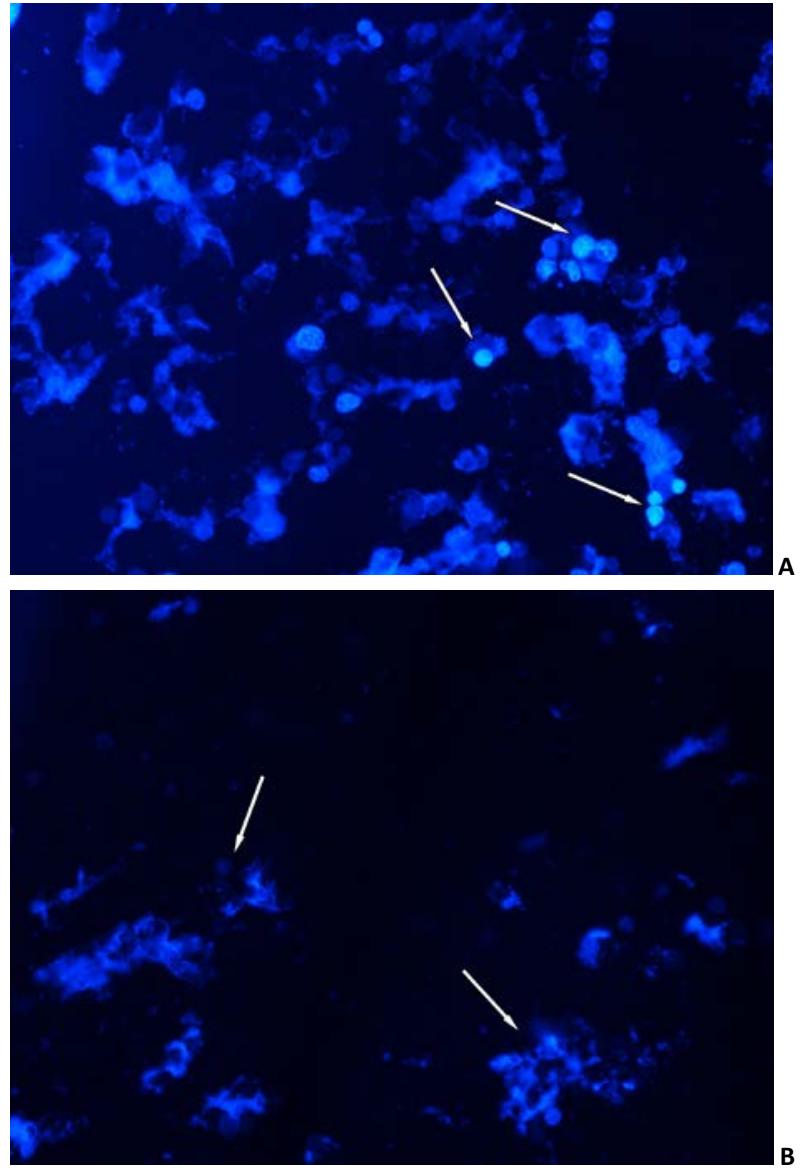

Figure 2. Cell line Caki-1: A) $24 \mathrm{~h}$ after exposure to the Gratiola officinalis extract at a concentration of $0.9 \mathrm{mg} / \mathrm{ml}$ (arrows denotes apoptotic bodies); B) 48 hours after exposure to the Gratiola officinalis extract (arrows labeled cellular debris), the mode of fluorescence at $435-485 \mathrm{Hm}$, Hoechst 33258 staining. $\times 200$.

24 hours after extract exposure. LCFV did not change at $0.035 \mathrm{mg} / \mathrm{ml}$ of Gratiola officinalis extract in the cell culture of Caki-1 (Table 1). The number of apoptotic cells at the stage of pyknosis increased (by $31.5 \%$ more), the proliferation index was 0.97 , the cells in mitosis increased by $1.3 \%$. The number of cells in apoptosis increased by $11.2 \%$ when exposed to $0.18 \mathrm{mg} / \mathrm{ml}$ of
Gratiola officinalis extract, which was due to an increase in cells at the stage of pyknosis (80.7\%).

A decrease of $63.3 \%$ in LCFV was observed at the concentration of $0.9 \mathrm{mg} / \mathrm{ml}$ of Gratiola officinalis extract (Figure 2). Also, an increase in the number of apoptotic cells by $17.6 \%$ was observed at concentration of $0.9 \mathrm{mg} / \mathrm{ml}$ of Gratiola officinalis extract (Figure 2), due to increasing of cells at the stage of pyknosis ( $47.5 \%$ more).

The proliferation index was 0.36. Cells in stages of metaphase, anaphase and telophase of mitosis were absent after exposure to Gratiola officinalis extract at a concentration of $0.9 \mathrm{mg} / \mathrm{ml}$ (Figure 2).

The decrease in LCFV in 97\%, 99\%, and 99\%, respectively, was observed 48 hours after exposure of Gratiola officinalis extract in cell culture of Caki-1 (Figure 2B): 0.035; 0.18 and $0.9 \mathrm{mg} / \mathrm{ml}$. An increase in the number of apoptotic cells by $22.9 \%$ (50\% in the stage of pyknosis and $50 \%$ apoptosis bodies) and cellular debris as result of cell degradation were noted at an extract concentration of $0.9 \mathrm{mg} / \mathrm{ml}$.

\section{Cell culture Sn12c}

The absence of cells in metaphase, anaphase and telophase phases of mitosis, and a low percentage of cells in apoptosis $(1.8 \pm 0.1)$ were observed after 24 hours in the control group of Sn12c culture (without exposure). After $48 \mathrm{~h}$, a $10 \%$ decrease in LCFV, a low percentage of cells in a mitosis state, and a low percentage of cells in apoptosis were observed in the control group of Sn12c culture (Figure 3, Table 2).

24 hours after exposure to concentrations of $0.035,0.18$ and $0.9 \mathrm{mg} / \mathrm{ml}$ of Gratiola officinalis extract, an increase in apoptotic cells was observed in Sn12c cell culture of $7.9 \%, 11.2 \%$, and $17.6 \%$, respectively, mainly in the pyknosis stage (more than $80 \%$ ) (Figure 4A). At concentration of $0.9 \mathrm{mg} / \mathrm{ml}$, a decrease in LCFV at $63.3 \%$, a low proliferation index of 0.36 and a lack of cells on stages of metaphase, anaphase and telophase mitosis were observed (Table 2).

The increase of ANCL up to $14 \%$ was observed 48 hours after exposure to $0.035 \mathrm{mg} / \mathrm{ml}$ of Gratiola officinalis extract. An increase in LCFV up to $19.5 \%$ was noted at extract concentration of $0.18 \mathrm{mg} / \mathrm{ml}$, the proliferation index was 1.19 . An increase in apoptotic cells (up to $92.9 \%$ at the stage of pyknosis) was noted only at $0.9 \mathrm{mg} / \mathrm{ml}$ (Figure 4B) (Table 2).

Decrease in LCFV to $94.6 \%$ was observed, and the proliferation index was 0.06 at extract concentration of $0.9 \mathrm{mg} / \mathrm{ml}$. 
Table 2. Morphometric parameters of Sn12c cells after exposure of Gratiola officinalis extract

\begin{tabular}{|c|c|c|c|c|c|c|}
\hline \multirow{2}{*}{$\begin{array}{l}\text { Groups ( } \mathrm{mg} / \mathrm{ml} \text { extract } \\
\text { concentration) }\end{array}$} & \multirow[t]{2}{*}{ LCFV } & \multirow{2}{*}{$\begin{array}{l}\text { The index of } \\
\text { proliferation }\end{array}$} & \multirow{2}{*}{$\begin{array}{l}\text { \% of cells in metaphase, } \\
\text { anaphase and telophase }\end{array}$} & \multirow{2}{*}{$\begin{array}{c}\% \text { apoptosis's cells in } \\
\text { field of view }\end{array}$} & \multicolumn{2}{|c|}{ \% cells in apoptosis } \\
\hline & & & & & Pyknosis & Apoptotic bodies \\
\hline \multicolumn{7}{|c|}{ After 24 hours } \\
\hline Control & $261.3 \pm 16.04$ & 1.00 & $0.0 \pm 0$ & $1.8 \pm 0.1$ & $71.7 \pm 3.8$ & $28.3 \pm 3.8$ \\
\hline Extract $0.035 \mathrm{mg} / \mathrm{ml}$ & $269.0 \pm 22.0$ & 1.03 & $0.2 \pm 0.1$ & $3.4 \pm 0.6^{*}$ & $91.9 \pm 2.6^{*}$ & $8.1 \pm 2.6^{*}$ \\
\hline Extract $0.18 \mathrm{mg} / \mathrm{ml}$ & $291.6 \pm 9.2$ & 1.11 & $0.5 \pm 0.2$ & $3.6 \pm 0.9 *$ & $55.7 \pm 11.3$ & $44.3 \pm 11.3$ \\
\hline Extract $0.9 \mathrm{mg} / \mathrm{ml}$ & $16.7 \pm 5.5^{*}$ & 0.06 & $0.0 \pm 0$ & $84.2 \pm 10 *$ & $100.0 \pm 0 *$ & $0.0 \pm 0 *$ \\
\hline \multicolumn{7}{|c|}{ After 48 hours } \\
\hline Control & $235.6 \pm 8.0$ & 1 & $0.4 \pm 0.1$ & $2.1 \pm 0.3$ & $48.8 \pm 15.4$ & $51.2 \pm 15.4$ \\
\hline Extract $0.035 \mathrm{mg} / \mathrm{ml}$ & $268.0 \pm 3.5^{*}$ & 1.14 & $0.6 \pm 0.1$ & $1.7 \pm 0.1$ & $77.5 \pm 1.4$ & $22.5 \pm 1.4$ \\
\hline Extract 0.18 mg/ml & $281.8 \pm 5.5^{*}$ & 1.19 & $0.0 \pm 0 *$ & $3.3 \pm 1.3$ & $50.4 \pm 11.2$ & $44.6 \pm 5.7$ \\
\hline Extract $0.9 \mathrm{mg} / \mathrm{ml}$ & $12.5 \pm 1.1^{*}$ & 0.05 & $0.0 \pm 0 *$ & $95.0 \pm 2.9 *$ & $100.0 \pm 0 *$ & $0.0 \pm 0 *$ \\
\hline
\end{tabular}

Data presented as mean with standard deviation - M \pm SD. LCFV, the average number of living cells in the field of view.

* - The differences are significant compared to the control group at $p<0.05$ and $T \geq 1.96$.

Table 3. Concentration of the Gratiola officinalis $L$. extract cause a pronounced apoptotic and cytotoxic activity after $24 \mathrm{~h}$ and $48 \mathrm{~h}$

\begin{tabular}{|c|c|c|c|c|c|c|c|}
\hline \multicolumn{4}{|c|}{ Apoptotic activity } & \multicolumn{4}{|c|}{ Cytostatic activity } \\
\hline \multicolumn{2}{|c|}{ Сакі-1 } & \multicolumn{2}{|c|}{ Sn12c } & \multicolumn{2}{|c|}{ Сакі-1 } & \multicolumn{2}{|c|}{ Sn12c } \\
\hline $24 \mathrm{~h}$ & $48 \mathrm{~h}$ & $24 \mathrm{~h}$ & $48 \mathrm{~h}$ & $24 \mathrm{~h}$ & $48 \mathrm{~h}$ & $24 \mathrm{~h}$ & $48 \mathrm{~h}$ \\
\hline $0.18-0.9 \mathrm{mg} / \mathrm{ml}$ & $0.9 \mathrm{mg} / \mathrm{ml}$ & $0.9 \mathrm{mg} / \mathrm{ml}$ & $0.035-0.9 \mathrm{mg} / \mathrm{ml}$ & $0.9 \mathrm{mg} / \mathrm{ml}$ & $0.035-0.9 \mathrm{mg} / \mathrm{ml}$ & $0.9 \mathrm{mg} / \mathrm{ml}$ & $0.9 \mathrm{mg} / \mathrm{ml}$ \\
\hline
\end{tabular}
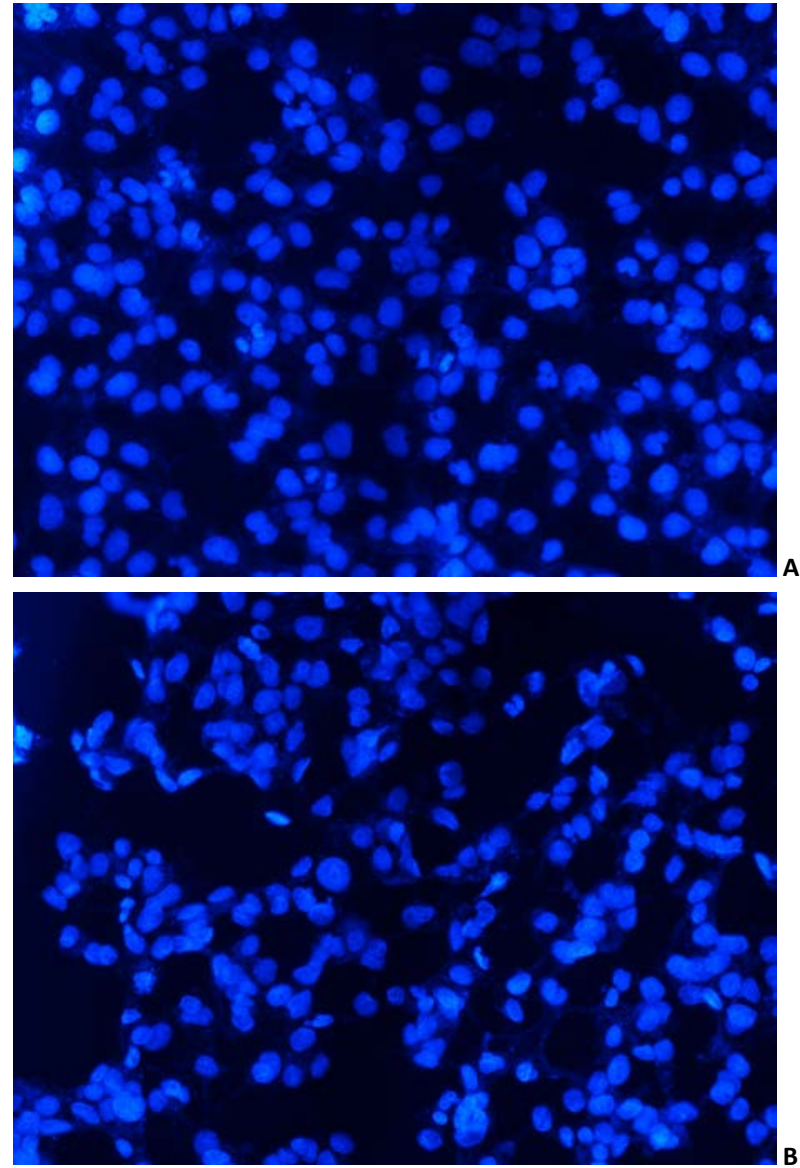

Figure 3. Cell line Sn12c without exposure: A) After $24 \mathrm{~h}$, B) After $48 \mathrm{~h}$, fluorescence at $435-485 \mathrm{~nm}$, Hoechst 33258 staining. $\times 200$.
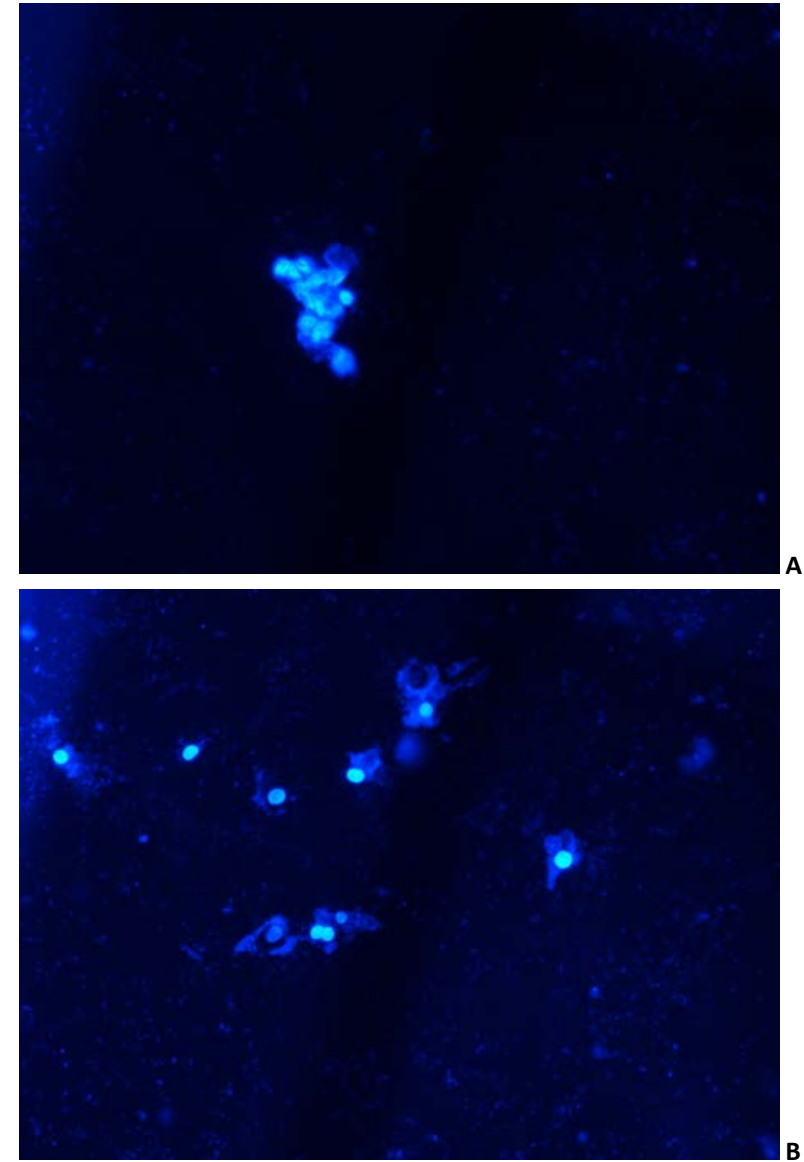

Figure 4. Cell line Sn12c after exposure of Gratiola officinalis extract at concentration of $0,9 \mathrm{mg} / \mathrm{ml}$ : A) after $24 \mathrm{~h}$; B) after $48 \mathrm{~h}$, fluorescence at 435-485 nm, Hoechst 33258 staining. x200. 


\section{Discussion}

In the experiments in vitro, activation of apoptosis was noted at all concentrations of Gratiola officinalis $L$. extract during the first day of exposure. The dependence was direct and linear, with increasing concentration, apoptotic activity increased. After 48 hours, this activity was maintained only at Gratiola officinalis $L$. extract concentration of $0.9 \mathrm{mg} / \mathrm{ml}$. The apoptotic activity of the extract will manifest more in the culture of CaKi-1 after 24 hours. However, the extract induces apoptosis more after 48 hours for the culture of Sn12c cells. The result obtained indicates a greater sensitivity of the CaKi-1 culture. The cytotoxic activity of the extract does not differ after 24 hours in the cultures studied. After 48 hours, it is pronounced more in the culture of CaKi-1 (Table 3 ).

The antitumor properties of flavonoids are discussed in the literature [21-23]. The data obtained by us are consistent with the results of other authors demonstrating that flavonoids activate apoptosis in tumor cells $[24,25]$, while not having toxicity. Thus, it is known that the flavonoid Vogonin as part of the popular Chinese herbal remedy Huang-Qin (based on grass skullcap Baikal) induces apoptosis in a wide range of human tumor cells in vitro and inhibits tumor growth in vivo in various models of mouse tumors $[3,29-34]$. It is important that at doses lethal to tumor cells, vogonin showed absence of cytotoxicity for normal cells and had also no obvious toxicity with regard to animals [30-35].

Some authors suggest that apoptosis, induced in tumor cells by flavonoids, is not realized by caspase [26]. However, most authors think that flavonoids activate caspase $3[4,27,28]$. Other authors consider that flavonoids activate caspase $3[4,27,28]$. Previously, we found that flavonoid-containing extract of Gratiola officinalis $L$. is able to activate p53 in rat kidney cancer cells [13]. p53 can transcriptionally activate a number of target genes involved in cell death signaling including proapoptotic Bax and Bak, which regulate the release of cytochrome $c$ from the mitochondria, and result in cell apoptosis by activating the cleaving of caspase- 3 and caspase9 [36]. Thus, our data suggests that the extract may trigger the caspase pathway of apoptosis. Further studies of the mechanisms of antitumor action of Gratiola officinalis extract are necessary for possible clinical application.

\section{Conclusion}

As a result of our study, we established a pronounced antitumor and apoptotic activity of Gratiola officinalis extract against the cell cultures of human kidney cancer Caki-1 and Sn12c. The most sensitive culture of kidney cancer to the action of exract was CaKi-1. Apoptosis of tumor cells can be manifested in the form of nucleus pyknosis, the formation of apoptotic bodies and the emergence of cellular debris resulting from complete degradation of tumor cells. The apoptotic activity of the Gratiola officinalis extract depends on the concentration and occurs at a concentration of $0.18-0.90 \mathrm{mg} / \mathrm{ml}$.

\section{Funding}

The experimental study was funded by RFBR according to the research project № 18-015-00298 A. The synthesis and characteristics of the extract was funded by state assignment of Ministry of Health of Russian Federation. The morphological work done by Nikita A. Navolokin was supported by the Russian President's Scholarship SP-523.2016.4 (20162018).

Conflict of interest: nonde declared.

\section{References}

1. Wong MCS, Goggins WB, Yip BHK, Fung FDH, Leung C, Fang Y, et al. Incidence and mortality of kidney cancer: temporal patterns and global trends in 39 countries. Sci Rep 2017; 7(1): 15698. https://doi.org/10.1038/s41598-017-15922-4.

2. Ferreira JF, Luthria DL, Sasaki T, Heyerick A. Flavonoids from Artemisia annua L. as antioxidants and their potential synergism with artemisinin against malaria and cancer. Molecules 2010; 15(5): 3135-3170. https://doi.org/10.3390/molecules15053135.

3. Polier G, Ding J, Konkimalla BV, Eick D, Ribeiro N, Kohler R, et al. Wogonin and related natural flavones are inhibitors of CDK9 that induce apoptosis in cancer cells by transcriptional suppression of Mcl-1. Cell Death Dis 2011; 2(7): e182. https://doi.org/10.1038/cddis.2011.66.

4. Wang IK, Lin-Shiau SY, Lin JK. Induction of apoptosis by apigenin and related flavonoids through cytochrome $c$ release and activation of caspase- 9 and caspase-3 in leukaemia HL-60 cells. Eur J Cancer 1999; 35(10): 1517-1525. https://doi.org/10.1016/S0959-8049(99)00168-9.

5. Polukonova AV, Durnova NA, Kurchatova MN, Navolokin NA, Golikov AG. The chemical analysis and a method of producing a new from biological active composition of Gratiola Officinalis L. Khimija Rastitel'nogo Syr'ja 2013; (4): 165-173. Russian. https://dx.doi.org/10.14258/jcprm.1304165.

6. Polukonova NV, Kurchatova MN, Navolokin NA, Bucharskaja AB, Durnova NA, Maslyakova GN. A new extraction method of bioflavanoids from poisonous plant (Gratiola officinalis L.). Russ Open Med J 2014; 3: 0304. https://dx.doi.org/10.15275/rusomj.2014.0304.

7. Tkachenko N, Pravdin A, Terentjuk G, Navolokin N, Kurchatova M, Polukonova N. Inhibiton of photodynamic haemolysis by gratiola officinalis L. extract. Proc SPIE 2015; 9448: 94480P. https://doi.org/10.1117/12.2179862.

8. Tkachenko NV, Bykova EV, Pravdin AB, Navolokin NA, Polukonova NV, Bucharskaja $A B$, et al. Comparison of membrane-protective activity of antioxidants quercetine and Gratiola Officinalis L. extract under conditions of photodynamic haemolysis. Proc SPIE 2016; 9917: 99170L. https://dx.doi.org/10.1117/12.2228291.

9. Navolokin NA, Polukonova NV, Maslyakova GN, Bucharskaya AB Durnova NA. Effect of extracts of Gratiola officinalis and Zea mays on the tumor and the morphology of the internal organs of rats with transplanted liver cancer. Russ Open Med J 2012; 1: 0203. https://dx.doi.org/10.15275/rusomj.2012.0203.

10. Navolokin NA, Mudrak DA, Bucharskaya AB, Matveeva OV, Tychina SA, Polukonova NV, Maslyakova GN. Effect of flavonoid-containing extracts on the growth of transplanted sarcoma 45, peripheral blood and bone marrow condition after oral and intramuscular administration in rats. Russ Open Med J 2017: 6(3): e0304. https://dx.doi.org/10.15275/rusomj.2017.0304.

11. Navolokin NA, Polukonova NV, Maslyakova GN, Bucharskaya AB, Durnova NA. Internal organs morphology and tumors in laboratory rats with transplanted liver cancer PC-1 by oral intoduction containing extract of Gratiola (Gratiola Officinalis L.) and Anthocyan Maize (Zea Mays L.). Saratov J Med Sci Res 2013; 9(2): 213-220. Russian. https://elibrary.ru/item.asp?id=20203823.

12. Navolokin NA, Mudrak DA, Polukonova NV, Tychina SA, Korchakov NB, Bucharskaya AB, Maslyakova GN. Evaluation of the antitumor and anticachexia activity of Gratiola officinalis L. extract in rats with transplanted sarcoma 45. Siberian Journal of Oncology 2016; 15(1): $37-$ 43. Russian. https://dx.doi.org/10.21294/1814-4861-2016-15-1-37-43.

13. Navolokin NA, Mudrak DA, Polukonova NV, Bucharskaya AB, Korchakov NV, Maslyakova GN. Effects of Gratiola officinalis L. extract containing flavonoids on pathomorphism of inoculated renal cancer in rats. Eksperimental'naya i Klinicheskaya Farmakologiya 2017; 80(6): 19-23. https://elibrary.ru/item.asp?id=29453199.

14. Polukonova NV, Navolokin NA, Rajkova SV, Maslyakova GN, Bucharskaya AB, Durnovan NA, Shub GM. Anti-inflammatory, antipyretic and antimicrobial activity of flavonoid-containing extract of 
Gratiola officinalis I. Eksperimental'naya i Klinicheskaya Farmakologiya 2015; 78(1): 34-38. Russian. https://elibrary.ru/item.asp?id=23070045.

15. Navolokin NA, Skvortsova VV, Polukonova NV, Manaenkova EV, Pankratova LE, Kurchatova $M$, et al. Antituberculous in vitro activity of Gratiola officinalis extract. Eksperimental'naya $i$ Klinicheskaya Farmakologiya 2015; 78(4): 10-13. Russian. https://elibrary.ru/item.asp?id=23385865.

16. Rothenburger J, Haslinger E. Caffeic acid glycoside esters from Gratiola officinalis L. Eur J Org Chem 1994; 11: 1113-1115. https://dx.doi.org/10.1002/ilac.199419941110.

17. Rothenburger J, Haslinger E. New cucurbitacin glycosides from Gratiola officinalis. Monat Fuer Chemie 1995; 126(12): 1331-1339. https://doi.org/10.1007/BF00807062.

18. Kaya GI, Melzig MF. Quantitative determination of cucurbitacin E and cucurbitacin I in homeopathic mother tincture of Gratiola officinalis L. by HPLC. Pharmazie 2008; 63(12): 851-853. https://www.ncbi.nlm.nih.gov/pubmed/19177898.

19. Zia-UI-Haq M, Kausar A, Shahid SA, Qayum M, Ahmad S, Khan I. Phytopharmacological profile of Gratiola officinalis Linn: a review. Journal of Medicinal Plants Research 2012; 6(16): 3087-3092. https://dx.doi.org/10.5897/JMPR12.172.

20. Ali L, Rizvi TS, Ahmad M, Shaheen F. New iridoid glycoside from Gratiola officinalis. J Asian Nat Prod Res 2012; 14(12): 1191-1195. https://dx.doi.org/10.1080/10286020.2012.734299.

21. Kandaswami C, Lee LT, Lee PP, Hwang JJ, Ke FC, Huang YT, Lee MT. The antitumor activities of flavonoids. In Vivo 2005; 19(5): 895-909. https://www.ncbi.nlm.nih.gov/pubmed/16097445.

22. Batra $P$, Sharma AK. Anti-cancer potential of flavonoids: recent trends and future perspectives. 3 Biotech 2013; 3(6): 439-459. http://doi.org/10.1007/s13205-013-0117-5.

23. Chahar MK, Sharma N, Dobhal MP, Joshi YC. Flavonoids: A versatile source of anticancer drugs. Pharmacognosy Reviews 2011; 5(9): 1-12. https://dx.doi.org/10.4103/0973-7847.79093

24. Hashemzaei M, Far AD, Yari A, Heravi RE, Tabrizian K, Taghdisi SM, et al. Anticancer and apoptosis-inducing effects of quercetin in vitro and in vivo. Oncol Rep 2017; 38(2): 819-828. https://doi.org/10.3892/or.2017.5766.

25. Nguyen LT, Lee $Y-H$, Sharma AR, Park JB, Jagga S, Sharma G, Lee SS, Nam JS. Quercetin induces apoptosis and cell cycle arrest in triplenegative breast cancer cells through modulation of Foxo3a activity. Korean J Physiol Pharmacol 2017; 21(2): 205-213. https://doi.org/10.4196/kjpp.2017.21.2.205.

26. White JB, Beckford J, Yadegarynia S, Ngo N, Lialiutska T, d' Alarcao M. Some natural flavonoids are competitive inhibitors of Caspase-1, -3 and -7 despite their cellular toxicity. Food Chem 2012; 131(4): 14531459. https://dx.doi.org/10.1016/j.foodchem.2011.10.026.

27. Das A, Banik NL, Ray SK. Flavonoids Activated Caspases for Apoptosis in Human Glioblastoma T98G and U87MG Cells But Not in Human Normal Astrocytes. Cancer 2010; 116(1): 164-176. https://dx.doi.org/10.1002/cncr.24699.

28. Ahamad MS, Siddiqui S, Jafri A, Ahmad S, Afzal M, Arshad M. Induction of apoptosis and antiproliferative activity of naringenin in human epidermoid carcinoma cell through ROS generation and cell cycle arrest. PLOS ONE 2014; 9(10): e110003. https://dx.doi.org/10.1371/journal.pone.0110003.

29. Li-Weber M. New therapeutic aspects of flavones: the anticancer properties of Scutellaria and its main active constituents wogonin, baicalein and baicalin. Cancer Treat Rev 2009; 35: 57-68. https://dx.doi.org/10.1016/i.ctrv.2008.09.005.

30. Wang $W$, Guo QL, You QD, Zhang K, Yang Y, Yu J, et al. The anticancer activities of wogonin in murine sarcoma S180 both in vitro and in vivo. Biol Pharm Bull 2006; 29:1132-1137. https://doi.org/10.1248/bpb.29.1132.

31. Baumann S, Fas SC, Giaisi M, Muller WW, Merling A, Gulow K, et al. Wogonin preferentially kills malignant lymphocytes and suppresses Tcell tumor growth by inducing PLCgamma1- and Ca2+-dependent apoptosis. Blood 2008; 111: 2354-2363. https://doi.org/10.1182/blood-2007-06-096198.

32. Chung $H$, Jung $Y M$, Shin $D H$, Lee JY, Oh MY, Kim HJ, et al. Anticancer effects of wogonin in both estrogen receptor-positive and -negative human breast cancer cell lines in vitro and in nude mice xenografts. Int J Cancer 2008; 122: 816-822. https://dx.doi.org/10.1002/ijc.2318.

33. Lu N, Gao Y, Ling Y, Chen Y, Yang Y, Gu HY, et al. Wogonin suppresses tumor growth in vivo and VEGF-induced angiogenesis through inhibiting tyrosine phosphorylation of VEGFR2. Life Sci 2008; 82: 956963. https://dx.doi.org/10.1016/i.lfs.2008.02.013.

34. Fas SC, Baumann S, Zhu JY, Giaisi M, Treiber MK, Mahlknecht U, et al. Wogonin sensitizes resistant malignant cells to TNFalpha- and TRAILinduced apoptosis. Blood 2006; 108: 3700-3706. https://doi.org/10.1182/blood-2006-03-011973.

35. Peng J, Qi Q, You Q, Hu R, Liu W, Feng F, et al. Subchronic toxicity and plasma pharmacokinetic studies on wogonin, a natural flavonoid, in Beagle dogs. J Ethnopharmacol 2009; 124:257-262. https://dx.doi.org/10.1016/j.jep.2009.04.031.

36. Henry $H$, Thomas $A$, Shen $Y$ and White $E$. Regulation of the mitochondrial checkpoint in p53 mediated apoptosis confers resistance to cell death. Oncogene 2002; 21: 748-760. https://dx.doi.org/10.1038/sj.onc.1205125.

\section{Authors:}

Natalya V. Polukonova - DSc, Associate Professor, Department of General Biology, Pharmacognosy and Botany, Saratov State Medical University, Russia; Head of Laboratory of Cell Technologies, Research Institute of Fundamental and Clinical Uronephrology, Saratov State Medical University, Russia. http://orcid.org/0000-0001-9228-6808.

Nikita A. Navolokin - MD, Assistant, Department of Pathological Anatomy, Saratov State Medical University, Russia. http://orcid.org/0000-0001-78769758.

Alla B. Bucharskaya - Head of Centre of Collective Use, Research Institute of Fundmental and Clinic Uronephrology, Saratov State Medical University, Saratov, Russia. https://orcid.org/0000-0003-0503-6486.

Dmitry A. Mudrak - 6-year student, Saratov State Medical University, Saratov, Russia. http://orcid.org/0000-0001-7399-9204.

Maria A. Baryshnikova - Head of the Laboratory of Experimental Diagnosis and Biotherapy of Tumors, Research Institute of Experimental Diagnosis and Therapy of Tumors n.a. N.N. Blokhin of Russian Academy of Sciences, Head of Laboratory of Experimental Diagnostics and Biotherapy of Tumors, N.N. Blokhin National Medical Research Centre of Oncology, Moscow, Russia. ORCID: http://orcid.org/0000-0002-6688-8423.

Eugenia V. Stepanova - Leading Researcher, Laboratory of Experimental Diagnosis and Biotherapy of Tumors; Head of the Laboratory of Biomarkers and Mechanisms of Tumor Angiogenesis, Research Institute of Experimental Diagnosis and Therapy of Tumors n.a. N.N. Blokhin of Russian Academy of Sciences, Moscow, Russia.

Eliso S. Solomko - Senior Researcher, Laboratory of Experimental Diagnosis and Biotherapy of Tumors, Research Institute of Experimental Diagnosis and Therapy of Tumors n.a. N.N. Blokhin of Russian Academy of Sciences, Moscow, Russia. ORCID: https://orcid.org/0000-0002-8070-4707. Anna V. Polukonova - Laboratory Assistant-Researcher, Centre of Collective Use, Research Institute of Fundmental and Clinic Uronephrology, Saratov State Medical University, Saratov, Russia. ORCID: http://orcid.org/0000-0001-7198-1254.

Galina N. Maslyakova - MD, DSc, Professor, Head of Department of Pathologic Anatomy, Saratov State Medical University, Saratov, Russia. https://orcid.org/0000-0001-8834-1536. 